\title{
N-(2-(1H-benzo[d]imidazol-2-yl)Phenyl)-2- (Substituted-styryl)Aniline as Anti-proliferative Agents: Rejuvenating the Importance of Low Molecular Weight Ligands in Oncotherapeutics
}

\author{
Santosh Subhash Chhajed,", Pramodkumar P Gupta², Sanjay Kshirsagar', Sakshi Tomar, Debarshi \\ Kar Mahapatra ${ }^{3}$, Raji Sundararajan ${ }^{4}$
}

1Department of Pharmaceutical Chemistry, Institute of Pharmacy, MET's Bhujbal Knowledge City, Nashik, Maharashtra, INDIA. ${ }^{2}$ School of Biotechnology and Bioinformatics, D.Y. Patil University, Navi Mumbai, Maharashtra, INDIA.

${ }^{3}$ Department of Pharmaceutical Chemistry, Dadasaheb Balpande College of Pharmacy, Nagpur, Maharashtra, INDIA.

${ }^{4}$ School of Engineering Technology, Purdue University, West Lafayette, Indiana, USA.

\begin{abstract}
Background: The rationale behind the study involved that in individuality benzimidazolebased molecules demonstrates significant anti-proliferative activity; chalcone molecules like xanthohumol are known to express noteworthy anti-cancer activity; benzamide derived products show remarkable inhibition of HDAC (an emerging anti-proliferative target) and styrene-based compounds possesses notable anti-tumor activity. Materials and Methods: In this research, an attempt was made to synthesize and characterize a series of hybridized molecules of the prototype (E)- $N-(2-(1 \mathrm{H}$-benzo[d]imidazol-2-yl) phenyl)-2-(substituted-styryl)aniline which comprises of a benzimidazole function; along with a chalcone (or styryl) moiety linked by a benzamide. The study involved screening of the novel derivatives against non-small cell lung cancer cell line (H460; ATCC: HTB177) and human colorectal cancer cell line (HCT116; ATCC: CCL-247) using Propidium lodide assay. In silico docking study was also performed against protein tyrosine kinase (PDB ID: 2J5F) to determine the probable mechanism of action of the novel compounds. Results: The study reflected the profound role and positions of substitution on the phenyl moiety of the benzimidazole system. The compound DSTYR4 displayed most potent antiproliferative activity with $\mathrm{IC}_{50}$ values of $2.98 \mu \mathrm{M}$ against HCT116 cell line and $5.15 \mu \mathrm{M}$ against $\mathrm{H} 460$ cell line. Conclusion: The research fruitfully rejuvenates the potentials and importance of small molecular weight ligands for experimental oncology.
\end{abstract}

Key words: Benzimidazole, Benzamide, Styryl, Chalcone, Hybrid, Anti-proliferative.

\section{INTRODUCTION}

Cancer is the leading cause of mortality and morbidity after the heart diseases across the globe which affected 8.2 million lives in the year 2012. ${ }^{1}$ Despite enormous efforts in developing newer leads and novel chemotherapeutic strategies for treating various forms of cancer, this disease remained the key concern across the globe. The need for an urgent alternative or a search for unexplored classes of substances against cancer cells remained the foremost need amongst scientists, of which regulation of cellular proliferation is the important approach to understanding and regulate cancer.

Low Molecular Weight Ligands (LMWL) have gained popularity in the modulation of several targets owing to their therapeutic smart characteristics. Heterocyclics, bi-cyclic scaffolds, or hybridized compounds formed by the fusion of a heterocyclic scaffold with another molecule have shown better therapeutic activity than their parents, leading to their popularity in modern chemotherapeutics. Benzimidazole scaffold has offered
Submission Date: 12-07-2019; Revision Date: 31-12-2019; Accepted Date: 30-01-2020

DOI: 10.5530/ijper.54.2.49 Correspondence: Dr. Santosh S Chhajed, Ph.D, Associate Professor, Department of Pharmaceutical

Chemistry, Institute of Pharmacy, MET's Bhujbal Knowledge City, Nashik-422003, Maharashtra, INDIA. Phone: +91-9850-081911 E-mail: santosh_chhajed@ rediffmail.com

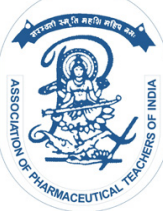

www.ijper.org 
several biological activities like anticancer, ${ }^{2}$ antimicrobial, ${ }^{3}$ anti-inflammatory, ${ }^{4}$ antimalarial, ${ }^{5}$ antihypertensive, ${ }^{6}$ etc. Several marketed drugs such as albendazole, mebendazole, tiabendazole, fenbendazole, lansoprazole, omeprazole, atacand, telmisartan, candesartan, mizolastine, bilastine, etc. are the classic examples of 1,2- or 1,3-disubstituted benzimidazole. ${ }^{7}$ Benzimidazole remained one of the most promising anti-cancer heterocyclic scaffolds which demonstrated successful anti-proliferative activity along with multifaceted attributes like inhibition of kinases, ${ }^{8}$ interaction with nuclear targets, ${ }^{9}$ increase sensitivity to chemotherapy, ${ }^{10}$ reduces the chances of metastasis ${ }^{11}$ and reduces resistance of drug influx. ${ }^{12}$ A number of benzimidazole hybrids like oxindole, ${ }^{13}$ quinazoline, ${ }^{14}$ coumarin, ${ }^{15}$ pyrazole, ${ }^{16}$ etc. have demonstrated excellent activity and have reached the hall of fame at this moment.

Naturally occurring compounds having styryl function have started attracting the medicinal chemists in synthesizing diverse styryl compounds and sequentially screen them for various pharmacological activity. One of such attempt gave 1-substituted-4-styryl[1,2,4] triazolo-[4,3-a] quinoxaline derivatives, ${ }^{17}$ when these compounds were tested for their biological importance, found to possess anticonvulsant activity. Once synthetic compounds have proven the pharmacological importance, large numbers of styryl substituted compounds were synthesized with the hope to obtain biologically important molecules. A large number of compounds are known to exist having styryl function attached to different heterocyclic nucleuses. From the structures of naturally obtained styryl compounds and their importance as anticancer agents, medicinal chemists then started to synthesize compounds containing styryl function attached to different heterocyclic rings and screened them for cytotoxic potential.

The rationale behind the study involved that in individuality benzimidazole-based molecules demonstrates significant anti-proliferative activity; chalcone molecules like xanthohumol are known to express noteworthy anti-cancer activity; benzamide derived products show remarkable inhibition of HDAC (an emerging antiproliferative target) and styrene-based compounds possesses notable anti-tumor activity (Figure 1).,18-20 In this research, an attempt was made to synthesize and characterize a series of hybridized molecules of the prototype (E)-N-(2-(1H-benzo[d]imidazol-2-yl) phenyl)-2-(substituted-styryl)aniline which comprises of a benzimidazole function; along with a chalcone (or styryl) moiety linked by a benzamide. The study involved screening of the novel derivatives against non-small cell lung cancer cell line (H460; ATCC: HTB177) and

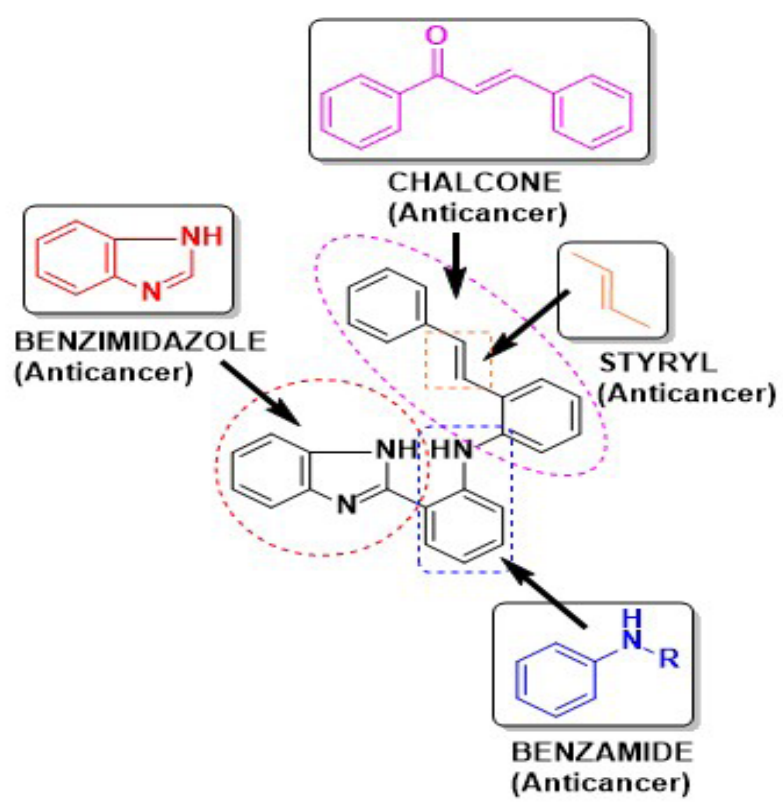

Figure 1: The rationale behind the designing of $(E)-N-(2-(1 \mathrm{H}-$ benzo[d]imidazol-2-yl)phenyl)-2-(substituted-styryl)aniline derivatives.

human colorectal cancer cell line (HCT116; ATCC: CCL-247) using Propidium Iodide assay. In silico docking study was also performed against protein tyrosine kinase (PDB ID: 2J5F) to determine the probable mechanism of action of the novel compounds.

\section{MATERIALS AND METHODS}

\section{Instrumentation}

All chemicals used for synthesis were purchased from Sigma-Aldrich and Merck. All other solvents and reagents were of analytical grade were procured from various commercial sources. Melting points were measured on Perfit melting point apparatus and are uncorrected. The infrared spectra were recorded in $\mathrm{KBr}$ discs on Win IR FTS 135 instrument. The ${ }^{1} \mathrm{H}-\mathrm{NMR}$ (400 MHz) spectra were recorded by Bruker spectrospin DPX-300 NMR using TMS (Sigma-Aldrich) as an internal standard. Mass spectra were obtained on JEOL-JMSDX 303 instrument. Elemental analyses $(\mathrm{C}, \mathrm{H}, \mathrm{N})$ were performed on Perkin-Elmer $240^{\circ} \mathrm{C}$ analyzer. All compounds were within $\pm 0.4 \%$ of the theoretical values. Thin layer chromatography was carried out using silica gel G-coated TLC plates (Merck).

\section{Synthesis of target compounds}

Synthetic protocol for $\mathrm{N}-(2-(1 \mathrm{H}-b e n z o[d] i m i d a z o l-2-y l)$ phenyl)-2-methylaniline (3)

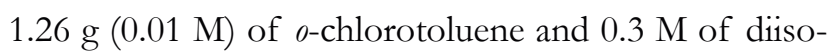
propylethylamine (DIPA) were dissolved in dry ethanol 


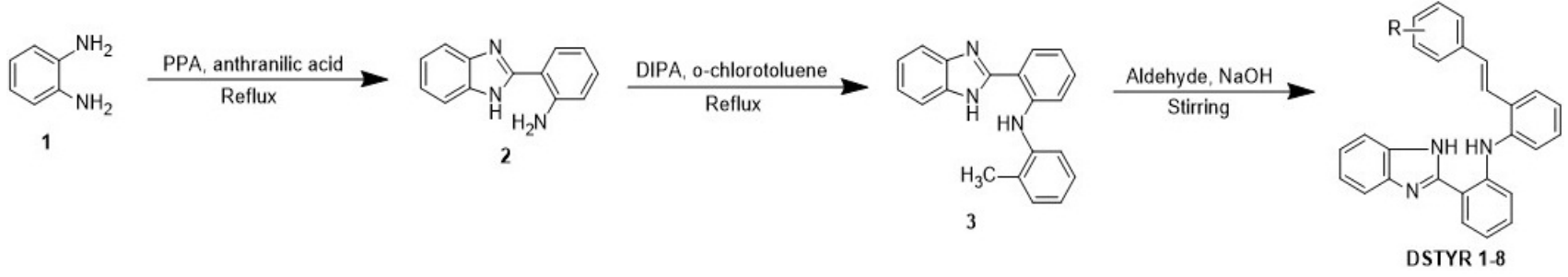

Figure 2: Synthetic protocol for synthesis of $(\mathrm{E})-\mathrm{N}-(2-(1 \mathrm{H}$-benzo[d]imidazol-2-yl)phenyl)-2-(substituted-styryl)aniline derivatives. (1) DSTYR1: R = H; (2) DSTYR2: R = 2-Cl; (3) DSTYR3: R = 4-Cl; (4) DSTYR4: R = 4-F; (5) DSTYR5: R = 2-OH; (6) DSTYR6: R = 4-OH; (7) DSTYR7: R = 2-NO $\mathrm{N}_{2}$; and (8) DSTYR8: $\mathrm{R}=4-\mathrm{OCH}_{3}$.

and added to $2.09 \mathrm{~g}(0.01 \mathrm{M})$ of 2-(1H-benzo[d]imidazol-2-yl)aniline (2). The content was refluxed in a closed steel vessel for $12 \mathrm{~h}$. The solvent was removed under vacuum. To the remaining residue $50 \mathrm{~mL}$ of chloroform was added and stirred till the solution was affected. The organic layer was washed with water and dried over sodium sulfate. The crude product was precipitated by concentrating the solution and was then purified by recrystallization (Figure 2).

Synthetic protocol for (E)-N-(2-(1H-benzo[d]imidazol-2yl)phenyl)-2-(substituted-styryl)aniline (DYSTR 1-8)

Equimolar quantities of different aldehydes and N-(2(1H-benzo[d]imidazol-2-yl)phenyl)-2-methylaniline (3) were taken in a $250 \mathrm{~mL}$ round bottomed flask and dissolved in $20 \mathrm{~mL}$ of ethanol. Further, $10 \mathrm{~mL}$ of $20 \%$ sodium hydroxide solution was added and the mixture was stirred for $5 \mathrm{~h}$. The reaction mixture was cooled to room temperature and neutralized by adding cold dilute hydrochloric acid drop wise. The obtained product was filtered under vacuum and dried suitably.

\section{$\mathrm{N}$-(2-(1 H-benzo[d]imidazol-2-yl)-phenyl)-2-styryl)aniline (DSTYR1)}

m.p. $112-114^{\circ} \mathrm{C}$; yield: $66 \%$, Rf: 0.36 [Benzene: Ethylacetate (9:1)]; IR: 3345.23 (N-H str), 3109.04 (aromatic C-H str), 1643.76 (aromatic $\mathrm{C}=\mathrm{C}$ str), $1613.62(\mathrm{C}=\mathrm{C}$ str of alkenes); ${ }^{1} \mathrm{H}-\mathrm{NMR}\left(\delta \mathrm{ppm}, \mathrm{CDCl}_{3}\right): \delta 4.1$ (s, $1 \mathrm{H}$, $\mathrm{N}-\mathrm{H}$ of benzimidazole ring), $\delta$ 6.9-8.1 (m, $17 \mathrm{H}, \mathrm{Ar}-\mathrm{H}) \delta$ 5.1 (s, $1 \mathrm{H}, \mathrm{N}-\mathrm{H}$, benzamine), $\delta 6.8$ (d, $1 \mathrm{H}$, vinylic), $\delta 6.5$ (d, $1 \mathrm{H}$, vinylic); MS (m/e): 387 [M+]; Elemental analysis (\%) found (calculated): C 83.45 (83.69), H 5.36 (5.46), N 10.71 (10.84).

$\mathrm{N}$-(2-(1 H-benzo[d]imidazol-2-yl)phenyl)-2-(2chlorostyryl)aniline (DSTYR2)

m.p. $78-80^{\circ} \mathrm{C}$; yield: $60 \%$; Rf: 0.42 [Benzene: Ethylacetate (9:1)]; IR: 3326.91 (N-H str), 3163.52 (aromatic C-H str), 1621.11 (aromatic $\mathrm{C}=\mathrm{C}$ str), 1600.32 (C=C str alkenes); ${ }^{1} \mathrm{H}-\mathrm{NMR}\left(\delta \mathrm{ppm}, \mathrm{CDCl}_{3}\right): \delta 4.4(\mathrm{~s}, 1 \mathrm{H}, \mathrm{N}-\mathrm{H}$ of benzimidazole ring), $\delta 6.9-8.5(\mathrm{~m}, 16 \mathrm{H}, \mathrm{Ar}-\mathrm{H}) \delta 4.5$ (s, $1 \mathrm{H}, \mathrm{N}-\mathrm{H}$ of benzamine), $\delta 6.9$ (d, $1 \mathrm{H}$, vinylic), $\delta 6.5$ (d, $1 \mathrm{H}$, vinylic); MS (m/e): $421[\mathrm{M}+]$; Elemental analysis (\%) found (calculated): C 76.67 (76.86), H 4.37 (4.78), N 9.83 (9.96).

$\mathrm{N}$-(2-(1 H-benzo[d]imidazol-2-yl)phenyl)-2-(4chlorostyryl)aniline (DSTYR3)

m.p. $198-200^{\circ} \mathrm{C}$; yield: 74\%; Rf: 0.59 [Benzene: Ethylacetate (9:1)]; IR: 3385.01 (N-H str) 3022.04 (aromatic C-H str), 1639.42 (aromatic $\mathrm{C}=\mathrm{C}$ str), 1602.00 (C=C str of alkenes); ${ }^{1} \mathrm{H}-\mathrm{NMR}\left(\delta \mathrm{ppm}, \mathrm{CDCl}_{3}\right): \delta 4.0(\mathrm{~s}, 1 \mathrm{H}, \mathrm{N}-\mathrm{H}$ ring), $\delta 6.8-7.7(\mathrm{~m}, 16 \mathrm{H}, \mathrm{Ar}-\mathrm{H}) \delta 4.5(\mathrm{~s}, 1 \mathrm{H}, \mathrm{N}-\mathrm{H}$ of benzamine), $\delta 6.2$ (d, $1 \mathrm{H}$, vinylic), $\delta 6.5$ (d, $1 \mathrm{H}$, vinylic); MS (m/e): $421[\mathrm{M}+]$; Elemental analysis (\%) found (calculated): C 76.72 (76.86), H 4.69 (4.78), N 9.72 (9.96).

$\mathrm{N}$-(2-(1 H-benzo[d]imidazol-2-yl)phenyl)-2-(4fluorostyryl)aniline (DSTRY4)

m.p. $244-246^{\circ} \mathrm{C}$; yield: 65\%; Rf: 0.51 [Chloroform: Methanol (9:1)]; IR: 3340.02 (N-H str), 3174.02 (aromatic C-H str), 1624.09 (aromatic $\mathrm{C}=\mathrm{C}$ str), 1610.29 (C=C str of alkenes); ${ }^{1} \mathrm{H}-\mathrm{NMR}\left(\delta \mathrm{ppm}, \mathrm{CDCl}_{3}\right): \delta 3.7(\mathrm{~s}, 1 \mathrm{H}$, $\mathrm{N}-\mathrm{H}$ of benzimidazole ring), $\delta$ 6.6-7.9 (m, $16 \mathrm{H}, \mathrm{Ar}-\mathrm{H})$ $\delta 4.2$ (s, $1 \mathrm{H}, \mathrm{N}-\mathrm{H}$ of benzamine), $\delta 6.5$ (d, $1 \mathrm{H}$, vinylic), $\delta 6.6(\mathrm{~d}, 1 \mathrm{H}$, vinylic); MS (m/e): $405[\mathrm{M}+]$; Elemental analysis (\%) found (calculated): C 79.89 (79.98), H 4.92 (4.97), N 10.27 (10.36).

$\mathrm{N}$-(2-(1 H-benzo[d]imidazol-2-yl)phenyl)-2-(2hydroxystyryl)aniline (DSTYR5)

m.p. $66-68^{\circ} \mathrm{C}$; yield: 60\%; Rf: 0.51 [Chloroform: Methanol (9:1)]; IR: 3283.82 (O-H str), 3034.08 (aromatic C-H str), 1629.62 (aromatic $\mathrm{C}=\mathrm{C}$ str),1602.22 (C=C str of alkenes); ${ }^{1} \mathrm{H}-\mathrm{NMR}\left(\delta \mathrm{ppm}, \mathrm{CDCl}_{3}\right): \delta 4.0$ (s, $1 \mathrm{H}$, $\mathrm{N}-\mathrm{H}$ of benzimidazole ring), $\delta$ 6.6-8.3 (m, $16 \mathrm{H}, \mathrm{Ar}-\mathrm{H})$ $\delta 4.2$ (s, $1 \mathrm{H}, \mathrm{N}-\mathrm{H}$ of benzamine), $\delta 6.6$ (d, $1 \mathrm{H}$, vinylic), $\delta 6.9$ (d, 1H, vinylic), $\delta 10.5$ (s, 1H, Ar-OH); MS(m/e): $405[\mathrm{M}+]$; Elemental analysis (\%) found (calculated): C 80.31 (80.37), H 5.19 (5.25), N 10.31 (10.41).

$\mathrm{N}$-(2-(1 H-benzo[d]imidazol-2-yl)phenyl)-2-(4hydroxystyryl)aniline (DSTYR6)

m.p. $78-80^{\circ} \mathrm{C}$; yield: $70 \%$; Rf: 0.56 [Chloroform: methanol (8:2)]; IR: 3283.82 (O-H str), 3034.08 (aromatic 
C-H str), 1629.62 (aromatic $\mathrm{C}=\mathrm{C}$ str),1602.22 (C=C str of alkenes); ${ }^{1} \mathrm{H}-\mathrm{NMR}\left(\delta \mathrm{ppm}, \mathrm{CDCl}_{3}\right): \delta 4.2(\mathrm{~s}, 1 \mathrm{H}$, $\mathrm{N}-\mathrm{H}$ of benzimidazole ring), $\delta 6.5-7.8(\mathrm{~m}, 16 \mathrm{H}, \mathrm{Ar}-\mathrm{H})$ $\delta 5.1$ (s, $1 \mathrm{H}, \mathrm{N}-\mathrm{H}$ of benzamine), $\delta 6.6$ (d, 1H, vinylic), $\delta 6.9$ (d, $1 \mathrm{H}$, vinylic), $\delta 8.9$ (s, $1 \mathrm{H}, \mathrm{Ar}-\mathrm{OH})$, MS (m/e): $403[\mathrm{M}+]$; Elemental analysis (\%) found (calculated): C 80.09 (80.37), H 5.18 (5.25), N 10.35 (10.41).

\section{$\mathrm{N}$-(2-(1 H-benzo[d]imidazol-2-yl)phenyl)-2-(2-nitrostyryl)} aniline (DSTYR7)

m.p. $192-194^{\circ} \mathrm{C}$; yield: 60\%; Rf: 0.40 [Benzene: Ethylacetate (9:1)]; IR: 3305.34 (N-H str), 3109.04 (aromatic C-H str), 1633.00 (aromatic C=C str), 1613.62 (C=C str of alkenes), 1479.36 and $1507.37(\mathrm{~N}=\mathrm{O}$ str sym. and antisym. respectively); ${ }^{1} \mathrm{H}-\mathrm{NMR}:\left(\delta \mathrm{ppm}, \mathrm{CDCl}_{3}\right): \delta 4.1$ (s, $1 \mathrm{H}, \mathrm{N}-\mathrm{H}$ of benzimidazole ring), $\delta 6.5-7.8(\mathrm{~m}, 16 \mathrm{H}$, Ar-H) $\delta 5.1$ (s, 1H, N-H of benzamine), $\delta 6.8$ (d, $1 \mathrm{H}$, vinylic), $\delta 6.9$ (d, 1H, vinylic); MS (m/e): $434[\mathrm{M}+]$; Elemental analysis (\%) found (calculated): C 74.89 (74.98), H 4.58 (4.66), N 12.52 (12.95).

$\mathrm{N}$-(2-(1 H-benzo[d]imidazol-2-yl)phenyl)-2-(4methoxystyryl)aniline (DSTYR8)

m.p. 264-266 $26^{\circ}$; yield: 60\%; Rf: 0.39 [Chloroform: Methanol (9:1)]; IR: 3460 (NH str), 3050.04 (Ar C-H str), 1602.62 ( $\mathrm{C}=\mathrm{C}$ str of alkenes), 1639.60 ( $\mathrm{Ar} \mathrm{C}=\mathrm{C}$ str), 1203.32(C-O str,Aryl-O-C) ${ }^{1} \mathrm{H}-\mathrm{NMR}\left(\delta \mathrm{ppm}, \mathrm{CDCl}_{3}\right) \delta$ 1.2 (s, $3 \mathrm{H}$, Methoxy) $\delta 4.3$ (s, $1 \mathrm{H}, \mathrm{N}-\mathrm{H}$ of ring), $\delta 6.5-8.2$ $(\mathrm{m}, 16 \mathrm{H}, \mathrm{Ar}-\mathrm{H}) \delta 4.9$ (s, 1H, N-H of benzamine), $\delta 6.8$ (d, 1H, vinylic), $\delta 6.9$ (d, 1H, vinylic); $\mathrm{MS}(\mathrm{m} / \mathrm{e})$ : $419[\mathrm{M}+]$; Elemental analysis (\%) found (calculated): C 80.46 (80.55), H 5.49 (5.55), N 9.89 (10.06).

\section{In silico molecular docking}

The molecular docking of ligands into the 3-D X-ray structure of protein tyrosine kinase (PDB ID: 2J5F) was carried out using Molecular Design Suite (MDS) software package (v. 3.5). The ligand-protein complex was created based on the X-ray structure of proteins obtained from protein data bank. All compounds were constructed using Chem Draw Ultra v. 8.0 and the energy minimization was done using the Merck Molecular Force Field (MMFF) application. The work is initiated by keeping the program parameter to their default options and the docking was carried out by MDS into the 3D model of the catalytic site of the enzyme. The comparative docking experiments of designed compounds with known kinase inhibitor imatinib were performed. The Genetic Algorithm (GA) implemented in the MDS has been used to dock inhibitors into the catalytic site of the target. ${ }^{21}$ The obtained results were assessed in terms of the binding score.

\section{Anticancer screening by Propidium lodide assay (PI assay)}

The non-small cell lung cancer cell line (H460; ATCC: HTB177) and human colorectal cancer cell line (HCT116; ATCC: CCL-247) were procured from NCCS, Pune. All cell lines were grown in media RPMI1640 enriched with fetal bovine serum (10\%). All cell lines were grown under physiological conditions, specifically at $37^{\circ} \mathrm{C}$ with $5 \% \mathrm{CO}_{2}$ and passed every 2-3 days. The cell lines were freeze at $-20^{\circ} \mathrm{C}$ for $24 \mathrm{~h}$ during which the seed cells (at a density range of 15003000 cells/well) in $180 \mu \mathrm{L}$ of culture medium in tissueculture-grade 96 well plate are allowed to recover for $24 \mathrm{~h}$ in humidified $5 \% \mathrm{CO}_{2}$ incubator at $37 \pm 1^{\circ} \mathrm{C}$. After $24 \mathrm{~h}, 20 \mu \mathrm{L}$ solutions $(1,3,10,30,100,300$ and 1000 $\mu \mathrm{M}$ of synthesized compounds dissolved in DMSO not exceeding $0.5 \%$ and in cell medium), was added to wells and incubated for $48 \mathrm{~h}$ in humidified $5 \% \mathrm{CO}_{2}$ at $37 \pm 1^{\circ} \mathrm{C}$. After incubation, the medium was removed from wells and washed with Phosphate Buffered Saline (PBS). About $100 \mu \mathrm{L}$ of PI working solution $(7 \mu \mathrm{g} / \mathrm{mL}$ per well) was added and plates were stored at $-80^{\circ} \mathrm{C}$ overnight. After thawing, the fluorescence of plates was measured using the POLAR star optima plate reader at excitation $536 \mathrm{~nm}$ and emission $590 \mathrm{~nm}^{22}$

The anti-cancer potentials of compounds were calculated using the formula given below:

$\%$ Cytotoxicity $=\left\{1-\frac{[\text { corrected RFU of sample }]}{\text { corrected RFU control }}\right\} \times 100$

Corrected control $=[$ Average RFU of control Average RFU of blank]

Corrected sample $=[$ Average RFU of sample Average RFU of blank]

Where, RFU: Relative fluorescence unit; Control: Well containing cancerous cell and PI solution; Blank: Well containing only PI solution.

\section{Statistical analysis}

The results acquired from experiments were expressed as mean. The differences between the control and treated groups were tested for significance using ANOVA followed by Dunnett's $t$-test, with $P<0.05$ were considered as significant.

\section{RESULTS AND DISCUSSION}

\section{In silico docking}

The docking analysis into the active site of enzyme tyrosine protein kinase reveals that compounds having 


\begin{tabular}{|c|c|}
$\begin{array}{c}\text { Table 1: Docking Score of the synthesized deriva- } \\
\text { tives. }\end{array}$ \\
\hline Compound & Dock Score \\
\hline DSTYR1 & -11.27 \\
\hline DSTYR2 & -10.81 \\
\hline DSTYR3 & -12.13 \\
\hline DSTYR4 & -10.91 \\
\hline DSTYR5 & -13.63 \\
\hline DSTYR6 & -5.99 \\
\hline DSTYR7 & -10.21 \\
\hline DSTYR8 & -13.23 \\
\hline Standard & -13.48 \\
\hline
\end{tabular}

docking score of $-11.27 \mathrm{kcal} / \mathrm{mol}$ (DSTYR1), -10.81 $\mathrm{kcal} / \mathrm{mol}$ (DSTYR2), $-12.13 \mathrm{kcal} / \mathrm{mol}$ (DSTYR3), $-10.91 \mathrm{kcal} / \mathrm{mol}$ (DSTYR4), $-13.63 \mathrm{kcal} / \mathrm{mol}$ (DSTYR5) and $-13.23 \mathrm{kcal} / \mathrm{mol}$ (DSTYR8), indicating affinity for the compounds with receptor protein kinase. DSTYR5 and DSTYR8 demonstrated the strongest affinity for the enzyme as compared to other compounds in the series. The low dock score for DSTYR5 compared to standard imatinib, indicated stronger affinity for protein kinase (Table 1).

\section{Chemistry}

The IR spectra demonstrated some important characteristics of the synthesized molecules. The stretching of the amides was predominantly characterized by peaks in range $3280-3385 \mathrm{~cm}^{-1}$. Two prominent features of the aromatic ring were observed in the spectrum. An aromatic $\mathrm{C}-\mathrm{H}$ stretching in the range $3050-3200 \mathrm{~cm}^{-1}$ and aromatic $\mathrm{C}=\mathrm{C}$ stretching was identified in the range 1610-1650 $\mathrm{cm}^{-1}$. The alkene $(\mathrm{C}=\mathrm{C})$ stretching was primarily observed in the range of $1600-1610 \mathrm{~cm}^{-1}$. The ${ }^{1} \mathrm{H}$ NMR signified the prominent structural features. The amide proton appeared in the spectrum at two different places. The protons of benzimidazole were detected in the range 3.7-4.2 ppm, whereas the protons of benzamide were located at 4.2-5.1 ppm. The peaks observed at $6.6-8.5 \mathrm{ppm}$, represented the 16 aromatic protons. The vinylic proton appeared prominently in the range of 6.2-6.9 $\mathrm{ppm}$. The mass spectra described the base peaks corresponding or similar to their exact molecular mass. In-depth analysis of the mass spectrum described few key distinguishing features. The $\mathrm{m} / \mathrm{z} 117.2$ presented the benzo[d]imidazole fragment; $\mathrm{m} / \mathrm{z} 193.3$ signified the 2-phenyl- $1 H$-benzo[d]imidazole fragment; and $\mathrm{m} / \mathrm{z} 194.1$ represented the (E)-1-amine2-styrylbenzene part, which is equivalent to their molecular mass (Figure 3). Several fragment peaks also appeared in the $\mathrm{m} / \mathrm{z}$ range of $100-150$. The elemental

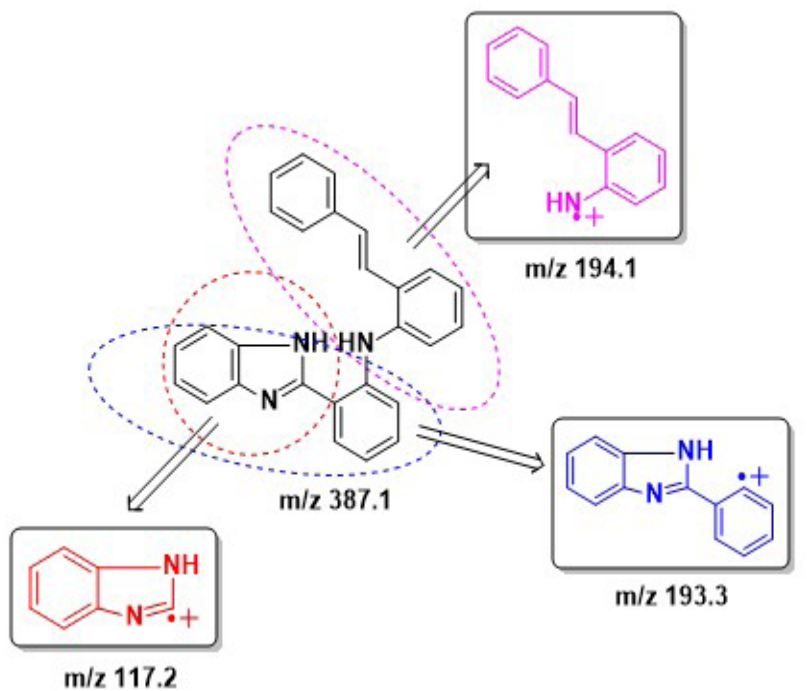

Figure 3: The fragmentation patterns of the prototype compound and the obtained products.

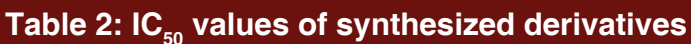
against HCT116 and $\mathrm{H} 460$ cell lines.

\begin{tabular}{|c|c|c|}
\hline \multirow{2}{*}{ Compound } & \multicolumn{2}{|c|}{$\mathbf{I C}_{\mathbf{5 0}}(\boldsymbol{\mu} \mathbf{M})$ against } \\
\cline { 2 - 3 } & $\mathbf{H C T 1 1 6}$ & $\mathbf{H 4 6 0}$ \\
\hline DSTYR1 & 83.3 & 59.3 \\
\hline DSTYR2 & 95.5 & 262.7 \\
\hline DSTYR3 & 20.81 & 14.67 \\
\hline DSTYR4 & 2.98 & 5.15 \\
\hline DSTYR5 & 44.15 & 51.96 \\
\hline DSTYR6 & 57.5 & 52.25 \\
\hline DSTYR7 & 76.7 & 79.2 \\
\hline DSTYR8 & 39.9 & 41.13 \\
\hline Standard & & \\
\hline
\end{tabular}

analysis of the compounds described the \% of carbon, nitrogen and hydrogen which were found in close agreement with the theoretical value.

\section{Anti-proliferative activity}

The PI assay showed that compounds DSTYR3, DSTYR4, STYR5 and STYR8 exhibited tremendous cytotoxic activity against HCT116 and H460 cell lines (Table 2). The compounds DSTYR3 and DSTYR4 were found to be the potent candidate with $\mathrm{IC}_{50}$ values of $20.81 \mu \mathrm{M}$ and $2.98 \mu \mathrm{M}$ against HCT116 cell line and $14.67 \mu \mathrm{M}$ and $5.15 \mu \mathrm{M}$ against $\mathrm{H} 460$ cell line, respectively. The unsubstituted phenyl ring analog (DSTYR1) possess mild anticancer activity with $\mathrm{IC}_{50}$ of $59.3 \mu \mathrm{M}$. Based on the Structure Activity Relationship (SARs) and rational designing of benzimidazole scaffold, the substituents and their positions played an imperative role 
in exhibiting anti-proliferative activity by modulating various unknown targets. The electron withdrawing substituents $(\mathrm{Cl}$ and $\mathrm{F})$ results in an increase in anticancer potential with the $\mathrm{IC}_{50}$ value of $14.67 \mu \mathrm{M}$ and $5.15 \mu \mathrm{M}$ respectively for compounds DSTYR3 and DSTYR4 against H460. The fluoro analog (DSTYR4) having a $\log P$ value of 6.68 , displayed the highest activity among all candidates, which might be indicative of the fact that the phenomenon of lipophilicity may be the driving factor. The lipophilicity (or hydrophobicity) of a compound is a crucial physical property that influences bilipid membrane permeation, dissolution rate, the bioavailability of compounds and controlling the interaction of drugs with the biological systems. Therefore, the candidate may interact with the target swiftly as compared to other analogs. From the observations, it was also noticed that analogs having electron withdrawing group in para position (DSTYR3) were privileged to express higher antiproliferative activity than ortho (DSTYR2); whereas the analogs having electron donating group in ortho position (DSTYR6) presented better activity than para (DSTYR5).

\section{CONCLUSION}

The study revealed the potential of $(\mathrm{E})-\mathrm{N}-(2-(1 \mathrm{H}-$ benzo[d]imidazol-2-yl)phenyl)-2-(substituted-styryl) aniline as active anti-proliferative candidates. The study reflected the profound role and positions of substitution on the phenyl moiety of the benzimidazole system. The compound DSTYR4 displayed most potent antiproliferative activity with $\mathrm{IC}_{50}$ values of $2.98 \mu \mathrm{M}$ against HCT116 cell line and $5.15 \mu \mathrm{M}$ against H460 cell line. However, docking into the catalytic site of enzyme protein kinase revealed no true correlation between the cytotoxic activity data and the binding affinity of the compounds. It may be assumed that all the synthesized derivatives exerted their cytotoxic effect by any other mechanism, which has not been tested in the present work. Further, the work encourages medicinal chemists of rationally selecting benzimidazole prototypes having well defined MOA and SARs in designing more effective inhibitors. In addition, it opens new avenues of heterocyclic research for the development of anti-cancer derivatives. The research fruitfully rejuvenates the potentials and importance of small molecular weight ligands for experimental oncology.

\section{ACKNOWLEDGEMENT}

Authors sincerely acknowledge Board of College and University Development (BCUD) Savitribai Phule Pune University for providing research grants. We also acknowledge thanks to SAIF Chandigarh for undertaking spectroscopic analysis.

\section{CONFLICT OF INTEREST}

Authors have no conflict of interest with the content and publication of this article.

\section{ABBREVIATIONS}

PBS: Phosphate Buffered Saline; SAR: Structure Activity Relationship; LMWL: Low molecular weight ligands; RFU: Relative Fluorescence Unit; PI: Propidium Iodide; DIPA: Diisopropylethylamine; MDS: Molecular Design Suite; PDB: Protein Data Bank; MMFF: Merck Molecular Force Field; GA: Genetic Algorithm; MOA: Mechanism of Action.

\section{REFERENCES}

1. http://www.who.int/mediacentre/factsheets/fs297/en/. 2018.

2. Chen K, Chu BZ, Liu F, Li B, Gao CM, Li LL, et al. New benzimidazole acridine derivative induces human colon cancer cell apoptosis in vitro via the ROS-JNK signaling pathway. Acta Pharmacol Sin. 2015;36(9):1074-84.

3. Soni LK, Narsinghani $T$, Sethi A. Anti-microbial benzimidazole derivatives: Synthesis and in vitro biological evaluation. Med Chem Res. 2012;21(12):4330-4.

4. Dighe S, Dighe N, Shinde PS, Lawre R, Nirmal S. Synthesis and Evaluation of Some New Benzimidazole Derivatives for their Anti-Microbial and AntiInflammatory Activities. Asian J Res Chem. 2014;7(12):1023-9.

5. Toro P, Klahn AH, Pradines B, Lahoz F, Pascual A, Biot C, et al. Organometallic benzimidazoles: Synthesis, characterization and antimalarial activity. Inorg Chem Commun. 2013;35:126-9.

6. Zhu W, Da Y, Wu D, Zheng H, Zhu L, Wang L, et al. Design, synthesis and biological evaluation of new 5-nitro benzimidazole derivatives as AT 1 antagonists with anti-hypertension activities. Bioorg Med Chem. 2014;22(7):2294-302.

7. Lemke TL, Williams DA. Foye's Principles of Medicinal Chemistry. Lippincott Williams and Wilkins. 2012.

8. Zheng $\mathrm{Y}$, Zheng M, Ling X, Liu Y, Xue Y, An L, et al. Design, synthesis, quantum chemical studies and biological activity evaluation of pyrazolebenzimidazole derivatives as potent Aurora A/B kinase inhibitors. Bioorg Med Chem Lett. 2013;23(12):3523-30.

9. Maji B, Kumar K, Kaulage M, Muniyappa K, Bhattacharya S. Design and Synthesis of New Benzimidazole-Carbazole Conjugates for the Stabilization of Human Telomeric DNA, Telomerase Inhibition and their Selective Action on Cancer Cells. J Med Chem. 2014;57(16):6973-88.

10. Parajuli B, Fishel ML, Hurley TD. Selective ALDH3A1 inhibition by benzimidazole analogues increase mafosfamide sensitivity in cancer cells. J Med Chem. 2014;57(2):449-61.

11. Schäfer S, Ferioli S, Hofmann T, Zierler S, Gudermann T, Chubanov V. Mibefradil represents a new class of benzimidazole TRPM7 channel agonists. Pflügers Archiv Eur J Physiol. 2016;468(4):623-34.

12. Nare B, Liu Z, Prichard RK, Georges E. Benzimidazoles, potent anti-mitotic drugs: Substrates for the P-glycoprotein transporter in multidrug-resistant cells. Biochemical Pharmacology. 1994;48(12):2215-22.

13. Kamal A, Nagaseshadri B, Nayak VL, Srinivasulu V, Sathish M, Kapure JS, et al. Synthesis and biological evaluation of benzimidazole-oxindole conjugates as microtubule-targeting agents. Bioorg Chem. 2015;63:72-84.

14. Sharma A, Luxami V, Paul K. Synthesis, single crystal and antitumor activities of benzimidazole-quinazoline hybrids. Bioorg Med Chem Lett. 2013;23(11):3288-94. 
15. Paul K, Bindal S, Luxami V. Synthesis of new conjugated coumarinbenzimidazole hybrids and their anticancer activity. Bioorg Med Chem Lett. 2013;23(12):3667-72.

16. Kalirajan R, Rathore L, Jubie S, Gowramma B, Gomathy S, Sankar S, et al. Microwave assisted synthesis and biological evaluation of pyrazole derivatives of benzimidazoles. Indian J Pharm Edu Res. 2010;44(4):358-62.

17. Wagle S, Adhikari AV, Kumari NS. Synthesis of some new 4-styryltetrazolo [1, 5-a] quinoxaline and 1-substituted-4-styryl [1, 2, 4] triazolo [4, 3-a] quinoxaline derivatives as potent anticonvulsants. Eur J Med Chem. 2009;44(3):1135-43.

18. Mahapatra DK, Bharti SK, Asati V. Anti-cancer chalcones: Structural and molecular target perspectives. Eur J Med Chem. 2015;98:69-114.
19. Mottamal M, Zheng S, Huang TL, Wang G. Histone deacetylase inhibitors in clinical studies as templates for new anticancer agents. Molecules. 2015;20(3):3898-941.

20. Long Y, Yu M, Li P, Islam S, Goh AW, Kumarasiri M, et al. Synthesis and biological evaluation of heteroaryl styryl sulfone derivatives as anticancer agents. Bioorg Med Chem Lett. 2016;26(23):5674-8.

21. Asati V, Bajaj S, Mahapatra DK, Bharti SK. Molecular modeling studies of some thiazolidine-2, 4-dione derivatives as 15-PGDH inhibitors. Med Chem Res. 2016;25(1):94-108.

22. Dengler WA, Schulte J, Berger DP, Mertelsmann R, Fiebig HH. Development of a propidium iodide fluorescence assay for proliferation and cytotoxicity assays. Anti-cancer Drugs. 1995;6(4):522-32.

\section{PICTORIAL ABSTRACT}

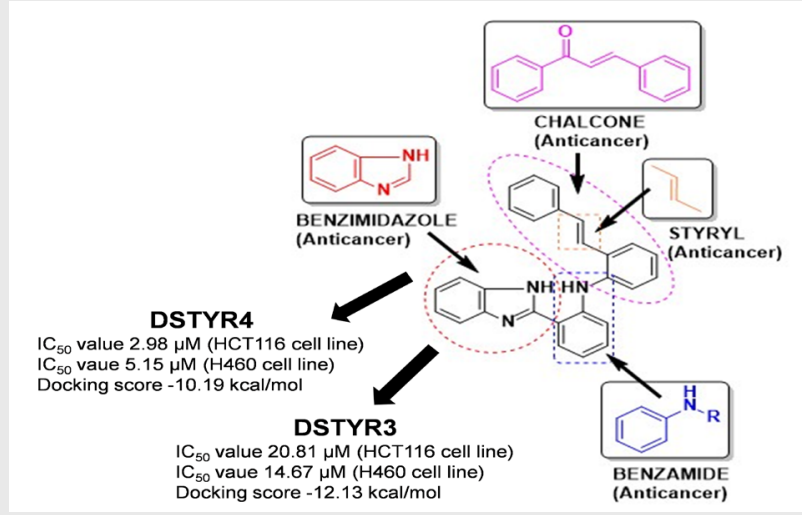

About Authors

\section{SUMMARY}

- A series of hybridized molecules of the prototype (E)-N-(2-(1H-benzo[d]imidazol-2-yl)phenyl)-2(substituted-styryl)aniline which comprises of a benzimidazole function; along with a chalcone (or styryl) moiety linked by a benzamide was designed.

- The compounds were characterized by sophisticated analytical techniques (IR, NMR, Mass spectroscopy) and the structure was established.

- DSTYR3 was found to be a potent candidate with IC $_{50}$ value of $20.81 \mu \mathrm{M}$ against HCT116 cell line and $\mathrm{IC}_{50}$ value of $14.67 \mu \mathrm{M}$ against $\mathrm{H} 460$ cell line.

- DSTYR4 was found to be the most potent candidate with $\mathrm{IC}_{50}$ values of $2.98 \mu \mathrm{M}$ against HCT116 cell line and $\mathrm{IC}_{50}$ value of $5.15 \mu \mathrm{M}$ against $\mathrm{H} 460$ cell line.

- Docking score of -11.27 (DSTYR1), -10.81 (DSTYR2), -12.13 (DSTYR3), -10.91 (DSTYR4), -13.63 (DSTYR5) and -13.23 (DSTYR8), indicating affinity for the compounds with receptor protein kinase.

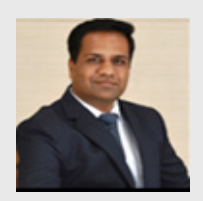

Dr. Santosh S. Chhajed is working as Associate Professor at Mumbai Education Trust's Institute of Pharmacy, Adgaon, Nashik. Dr. Santosh Chhajed is having teaching experience of 12 years of various Pharmaceutical Chemistry subjects at undergraduate as well postgraduate level. Dr. Chhajed has guided 20 scholars for their M. Pharm. Professor Chhajed has to his credit seven books in subjects like pharmaceutical chemistry, medicinal chemistry and pharmaceutical analysis and has published 40 papers in national and international journal of repute. Professor Chhajed is in receipt of Best Research Guide award in state level conference held in MET's Institutional Pharmacy in 2017 and he is in receipt of Best Teacher Award 2018 from Mahavir International, Nashik chapter. His research area is computational approaches for design of drugs, synthesis of small molecule heterocycles, bioanalytical method development, synthesis and analysis of drug impurities, toxicity predictions of new chemical entities and drug impurities

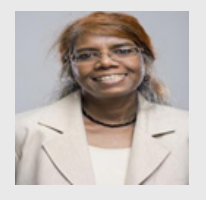

Dr Raji Sundarrajan is Professor at School of Engineering Technology, Purdue University, W Lafayette, Indiana. Dr Raji has done her Ph.D., in Electrical Engineering, Arizona State University, Tempe, AZ. Her research interest is electrical and electronics applications to medicine, health care and home health gadgets, modeling and simulation of biological systems power and high voltage engineering. Dr Raji is having about 130 publication including in journal, conference, book and chapters 


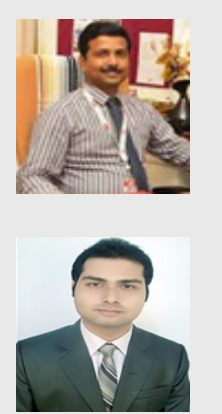

Dr Sanjay J. Kshirsagar is currently working as Principal MET's Institute of Pharmcy, Bhujbal Knowledge City, Nashik. Dr. Kshirsagar has done his Ph.D in Pharmaceutics from JNTU University Hyderabad in year 2014. He is having about 150 publicaton in national and international journal of repute. He has authored two books.

Debarshi Kar Mahapatra is currently an Assistant Professor at Department of Pharmaceutical Chemistry, Dadasaheb Balpande College of Pharmacy, Nagpur. He taught medicinal and computational chemistry at undergraduate and post-graduate levels and has mentored numerous students in various research projects. He has published several research papers, review articles, imperative case-studies in various reputed national and international journals and authored many book chapters. He presented his original contributions at several international platforms, for which he received several awards by a number of scientific and professional bodies. He has contributed several edited books, textbooks, lab manuals, book chapters and guide books on Medicinal Chemistry, Computational Chemistry and Pharmaceutics. Presently, he is serving as reviewer and editorial board member for several journals of national and international repute.

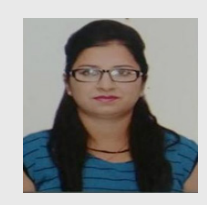

Sakshi Tomar is currently a Senior Research Fellow at Panjab University, Chandigarh. Her research interest includes pharmaceutical chemistry, pharmaceutical analysis. She was awarded UGC-RFMS (Research Fellowship for the Meritious Student) in her Ph.D. The emphasis of her present research is to modify the existing therapeutically useful osteoarthritic molecules for better solubility and bioavailability by preparing better polymorphic modifications, By preparing co-crystals, in-vitro compatibility, application of, X-Ray Diffraction, thermoanalytical and spectroscopic methods for characterization of APIs, cocrystals and polymorphs. She has published several research papers and review articles in various reputed national and international journals. She taught pharmaceutical analysis and medicinal chemistry at the undergraduate and postgraduate levels.

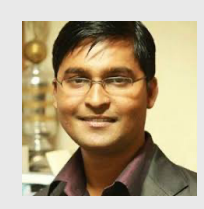

Pramodkumar P Gupta is an Assistant Professor at School of Biotechnology and Bioinformatics, D Y Patil Deemed to be University, Navi Mumbai Maharashtra, India. More thean 10 years of teaching experience of various bioinformatics and cheminformatics subjects at undergraduate and post graduate level. He has contributed numerous book chapters and research articles in national, international and has chaired organizing committee member, national advisory board member to national and international scientific events. Currently he is working in the field of "Protein kinase and drug discovery", "Metabolic pathway mapping and analysis". He is a recipient of Erasmus Mundus Doctoral Fellowship year (2016 - 2017) under Erasmus Mundus Euphrates Program, by European Union Commission, has completed his work at Proteomic Center, Vilnius University, Lithuania, Europe. He is a reviewer and editorial board member to numerous scientific journal and life member to various scientific society national and international. Research Interest: Bioinformatics, Biotechnology, Proteomics, Molecular modelling, Drug discovery.

Cite this article: Chhajed SS, Gupta PP, Kshirsagar S, Tomar S, Mahapatra DK, Sundararajan R. N-(2-(1H-benzo[d] imidazol-2-yl)Phenyl)-2- (Substituted-styryl)Aniline as Anti-proliferative Agents: Rejuvenating the Importance of Low Molecular Weight Ligands in Oncotherapeutics. Indian $\mathrm{J}$ of Pharmaceutical Education and Research. 2020;54(2):432-9. 